\title{
1 Perforin-2 Permeabilizes the Envelope of Phagocytosed Bacteria
}

3 Fangfang Bai, Ryan M. McCormack, Suzanne Hower, Gregory V. Plano, Mathias G. Lichtenheld,

4 George P. Munson*

Department of Microbiology and Immunology, Miller School of Medicine, University of Miami, Miami, 33163 USA

${ }^{*}$ Correspondence: George P. Munson, gmunson@miami.edu

9 Running title: Perforin-2

\section{Abstract}

Perforin-2, the product of the MPEG1 gene, limits the spread and dissemination of bacterial pathogens in vivo. It is highly expressed in murine and human phagocytes, and macrophages lacking Perforin-2 are compromised in their ability to kill phagocytosed bacteria. In this study we used Salmonella typhimurium as a model intracellular pathogen to elucidate the mechanism of Perforin-2's bactericidal activity. In vitro Perforin-2 was found to facilitate the degradation of antigens contained within the envelope of phagocytosed bacteria. In contrast, degradation of a representative surface antigen was found to be independent of Perforin-2. Consistent with our in vitro results a protease sensitive, periplasmic superoxide disumutase (SodCII) contributed to the virulence of $S$. typhimurium in Perforin-2 knockout but not wild-type mice. In aggregate our studies indicate that Perforin-2 breaches the envelope of phagocytosed bacteria facilitating the delivery of proteases and other antimicrobial effectors to sites within the bacterial envelope. 
 \\ Introduction}

Macrophages and neutrophils phagocytose microorganisms to remove them from blood and tissues. As the phagosome matures the multisubunit NADPH oxidase assembles on its membrane and reduces $\mathrm{O}_{2}$ to generate superoxide in the lumen of the phagosome (Karimi et al., 2014; Nauseef, 2004). The products of this respiratory burst -superoxide and subsequently other reactive oxygen species (ROS)- are bactericidal. The destruction and degradation of phagocytosed microbes is further facilitated by acidification of the phagosome and fusion with lysosomes that deliver oxygen-independent antimicrobial effectors such as lysozyme, glycosylases, proteases, and other hydrolases (Cederlund et al., 2011). Large antimicrobials such as proteases and other hydrolases are typically membrane impermeable molecules. This property is advantageous in that it allows them to be confined within lysosomes and phagolysosomes. However it also precludes them from reaching the internal components of phagocytosed bacteria. For example, lysozyme hydrolyzes $\beta(1,4)$-glycosidic bonds of peptidoglycan; the primary structural component of bacterial cell walls. In gram-negative bacteria peptidoglycan resides in the space between the outer and inner membranes; i.e., the periplasm. Thus, for these bacteria a breach of the outer membrane must precede lysozyme-dependent degradation of peptidoglycan (Ellison and Giehl, 1991; Martinez and Carroll, 1980). For hydrolases with targets in the cytosol of gram-negative bacteria the challenge is two-fold as their substrates are bound by both an inner and outer membrane.

Studies over the past two decades have shown that antimicrobial peptides such as the defensins and cathelicidins attack and disrupt bacterial membranes (Gallo et al., 1997; Turner et al., 1998; Wiesner and Vilcinskas, 2010; Zanetti, 2004). NMR studies of the cathelicidin LL-37 suggest that the peptide destabilizes the bacterial membrane by carpeting rather than penetrating the lipid bilayer (Henzler Wildman et al., 2003). Within phagolysosomes the murine cathelicidin CRAMP has been shown to be active against phagocytosed Salmonella; most likely by disruption of the bacterium's outer membrane (Kim et al., 2010; Rosenberger et al., 2004). Likewise, cathelicidin LL-37 may play a similar role in human phagocytes (Sonawane et al., 2011; Stephan et al., 2016). Nearly coincident with the initial descriptions of LL-37 and CRAMP the Mpeg1 gene was identified as a potential marker of mammalian macrophages due to its relatively high expression in mature human and murine macrophages (Gallo et al., 1997; Gudmundsson et al., 1996; Spilsbury et al., 1995). Mpeg1 encodes a $73 \mathrm{kDa}$ protein referred to as Perforin-2 and in their initial report Spilsbury et al. noted its partial homology to the membrane attack complex perforin (MACPF) domain of Perforin; the cytolytic protein of natural killer cells and cytotoxic $T$ lymphocytes (Spilsbury et al., 1995). Unlike the carpet mechanism of cathelicidins Perforin is a large polypeptide that polymerizes on target membranes. A concerted structural transition results in a pore through the lipid bilayer whose hydrophilic channel is lined with amphipathic $\beta$-strands donated by the MACPF domains (Law et al., 2010; Voskoboinik et al., 2015). It is through this channel, either at the cell surface as originally hypothesized or within endosomal membranes as a more recent study suggest, that granzyme proteases enter tumor and virally infected cells to facilitate their destruction and lysis (Lichtenheld et al., 1988; Podack et al., 1989; Thiery et al., 2011). MACPF domains are also present in the terminal complement proteins which form pores in the outer membranes of gram-negative bacteria through a similar mechanism of polymerization and structural transition (Dudkina et al., 2016).

Despite the homology of mammalian Perforin-2 to known pore forming proteins there was no further elaboration of its function until 2013; nearly two decades after the initial report of Spilsbury et al.(McCormack et al., 2013; Spilsbury et al., 1995). In 2013 McCormack et al. demonstrated that the expression of Perforin-2 correlated with the killing of phagocytosed gram-negative, - 
73 positive, and acid-fast bacteria in vitro (McCormack et al., 2013). Subsequent studies with

transgenic mice found that Perforin-2 -/- mice are unable to limit the proliferation and dissemination of infectious bacteria. Not surprisingly, Perforin-2 knockout mice succumb to infectious doses that are non-lethal to their wild-type littermates (McCormack et al., 2016; McCormack et al., 2015a; McCormack et al., 2015b). Moreover this defect is not limited to a particular route of infection nor pathogen. Nor is it limited to mammalian Perforin-2 as similar results have been reported with zebrafish as the model organism (Benard et al., 2015). In aggregate these latter studies have demonstrated that Perforin-2 is associated with broad spectrum bactericidal activity. In this study we utilized Salmonella typhimurium as a model pathogen to elucidate the mechanism of Perforin-2 dependent killing of phagocytosed bacteria.

\section{Results}

\section{Perforin-2 limits the survival of phagocytosed bacteria independent of ROS.}

Because the interactions between Salmonella sp. and macrophages have been extensively characterized, we chose to exploit the Salmonella/phagocyte paradigm to probe the mechanism of Perforin-2 dependent killing of phagocytosed bacteria (Steele-Mortimer, 2008). Accordingly, peritoneal exudate macrophages (PEMs) and neutrophils isolated from wild-type and Perforin-2 /- mice were infected with Salmonella enterica serovar Typhimurium (hereafter $S$. typhimurium). As expected from previous studies that have shown Salmonella survives within macrophages, the intracellular load of bacteria either increased or remained constant in wild-type phagocytes (Figure 1AB). However, Perforin-2 deficient phagocytes had significantly higher intracellular loads of $S$. typhimurium than wild-type phagocytes (Figure 1AB). This demonstrates that Perforin-2 limits the survival and/or replication of phagocytosed $S$. typhimurium and is consistent with previous studies that have shown Perforin-2 is a potent antimicrobial effector against Salmonella as well as gram-positive and acid-fast bacteria (Fields et al., 2013; McCormack et al., 2016; McCormack et al., 2015a; McCormack et al., 2015b). 


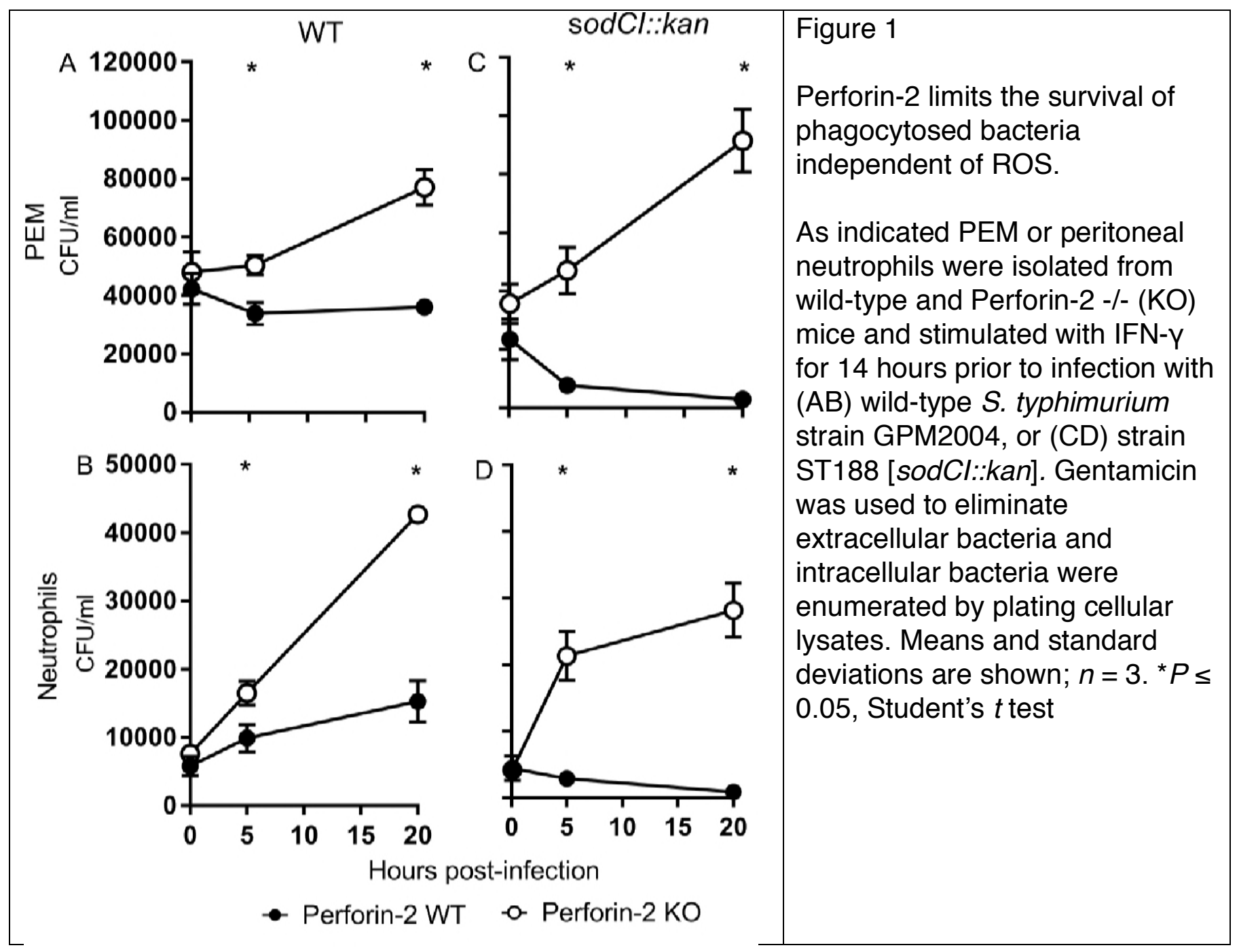

One of the aforementioned studies also investigated the relationship between reactive oxygen species (ROS) and Perforin-2 and concluded that the bactericidal activity of ROS was dependent upon Perforin-2 (McCormack et al., 2015a). This was based on two principle findings. First, chemical inhibition of ROS production significantly enhanced the survival of phagocytosed $S$. typhimurium -relative to mock treated cells- in wild-type but not Perforin-2 deficient PEMs. Second, wild-type PEMs killed a $\triangle$ sodCl strain of $S$. typhimurium much more efficiently than wildtype $S$. typhimurium. SodCl is a periplasmic superoxide dismutase that neutralizes ROS and thus promotes the survival of $S$. typhimurium within phagosomes (Krishnakumar et al., 2004; McCormack et al., 2015a). However, the sodCl mutant was found to be no less fit than the wildtype strain when Perforin-2 -/- PEMs were used. Thus, both a chemical and genetic analysis suggest that ROS is not a significant bactericidal effector when Perforin-2 is absent.

As with the previous study we observed similar effects with both PEMs and neutrophils. In either case the $S$. typhimurium sodCl mutant was efficiently killed by Peforin-2 proficient but not deficient phagocytes (Figure 1CD). The source of phagocytic ROS is the multisubunit NADPH oxidase NOX2 (Panday et al., 2015). Assembly of the enzymatic complex involves the translocation of cytosolic proteins to the endosomal membrane to form the active complex that generates the respiratory burst (Panday et al., 2015). Likewise Perforin-2, a transmembrane protein of cytosolic vesicles, dynamically translocates to and fuses with phagocytic vesicles containing bacteria (McCormack et al., 2015a; McCormack et al., 2015b). This raised the possibility that Perforin-2 is involved in the assembly and/or activation of the NADPH oxidase. If 
118 true the respiratory burst would be deficient in Perforin-2 -/- phagocytes and would account for

119 the survival of $S$. typhimurium sodCI mutants in Perforin-2 deficient phagocytes.

120 To determine whether or not Perforin-2 is required for ROS production a luminol based

121 chemiluminescence assay was used to quantify ROS productions in IFN-Y primed PEMs, peritoneal macrophages isolated without thioglycollate stimulation, and neutrophils from wild-type and Perforin-2 knockout mice. We found that ROS production was equally robust in wild-type and Perforin-2 -/- macrophages that were stimulated with PMA or LPS (Figure 2AB). The kinetics of ROS production was also similar as macrophages of both genotypes exhibited peak ROS production at $60 \mathrm{~min}$. To confirm that the chemiluminescent signal was due to ROS production by a NADPH oxidase, phagocytes were pretreated with diphenyleneiodonium chloride (DPI); an inhibitor of NAPDH oxidases. As expected DPI treated cells produced negligible amounts of ROS (Figure 2). Likewise, ROS production was also negligible in unstimulated macrophages (data not shown). As with macrophages, we found few statistically significant differences between ROS production in wild-type and Perforin-2 -/- neutrophils (Figure 2CD). Thus, we conclude that impaired ROS production cannot account for the survival of $S$. typhimurium $\Delta$ sodCl mutants in Perforin-2 -/- phagocytes. 

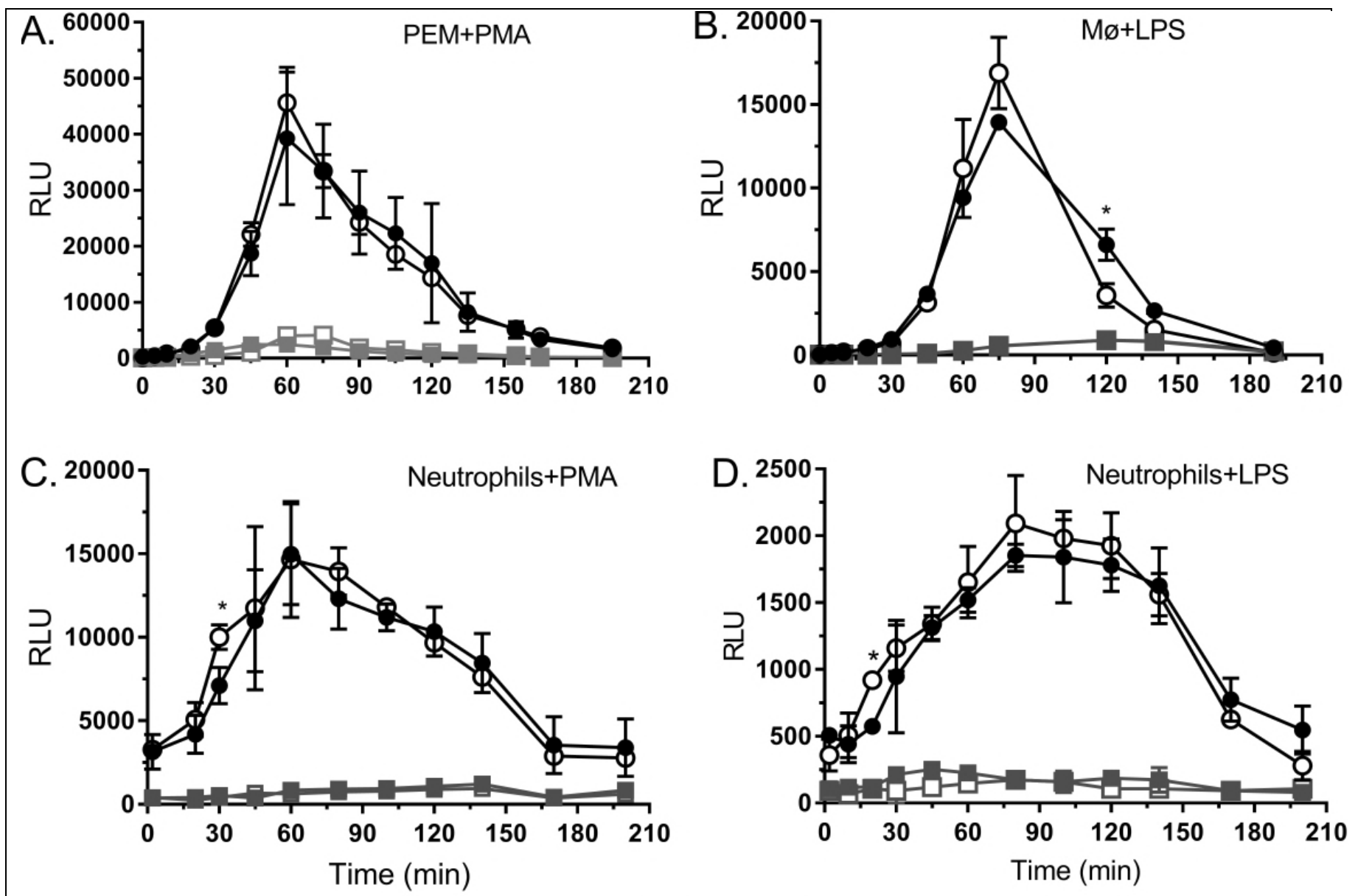

Figure 2
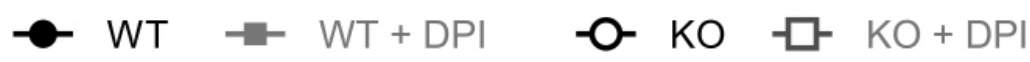

Perforin-2 is not required for ROS production in phagocytes.

As indicated wild-type and Perforin-2 -/- (KO) peritoneal $(A, B)$ macrophages and $(C, D)$ neutrophils were stimulated with PMA or LPS to elicit ROS production which was detected by luminal based chemiluminescence. An enhancer was added to amplify chemiluminescence when macrophages were used. As indicated some cells were also treated with DPI, an inhibitor of the phagocytic NAPDH oxidase. ROS activity is reported as mean relative light units (RLUs) $\pm \mathrm{SD} ; n=3 .{ }^{*} P \leq 0.05$, Student's $t$ test.

\section{SodCI and SodCII are functionally redundant in Perforin-2 -/- phagocytes.}

Having excluded the possibility that Perforin-2 deficiency results in impaired ROS production, we next considered the possibility that $S$. typhimurium sodCI mutants are resistant to ROS in Perforin-2 deficient but not proficient phagocytes. As the genome of $S$. typhimurium encodes a second periplasmic superoxide dismutase (SodCII) we considered the possibility that it provides resistance to ROS in Perforin-2 -/- phagocytes even though previous studies have concluded that SodCIl does not attenuate ROS toxicity in wild-type cells and animals (Kim et al., 2010; Krishnakumar et al., 2004). To determine whether or not SodCI and SodCII are functionally redundant we infected Perforin-2 proficient and deficient phagocytes with a sodCl sodCll double mutant. Unlike the $\triangle$ sodCl sodCl/ strain which was killed by wild-type but not Perforin-2 knockout phagocytes (Figure 1CD), the $\Delta$ sodCl sodCll::kan strain was killed by both Perforin- $2+/+$ and -/- 
bioRxiv preprint doi: https://doi.org/10.1101/274878; this version posted March 2, 2018. The copyright holder for this preprint (which was not certified by peer review) is the author/funder, who has granted bioRxiv a license to display the preprint in perpetuity. It is made available under aCC-BY-NC-ND 4.0 International license.

phagocytes (Figure $3 \mathrm{AB}$ ). Moreover, treatment with the NADPH oxidase inhibitor DPI

demonstrated that killing of the double mutant was ROS dependent in both Perforin- $2+/+$ and $-/-$ PEMs (Figure 4). Complementation of the double mutant with sodCll allowed the complemented strain to proliferate in Perforin-2 -/- but not wild-type phagocytes (Figure 3CD). Thus, in agreement with previous studies we conclude that SodCll does not protect against ROS in wildtype phagocytes. However, the nullification of SodCll is clearly dependent upon Perforin-2 because SodCII is able to protect phagocytosed $S$. typhimurium from the bactericidal effects of ROS in Perforin-2 -/- phagocytes.

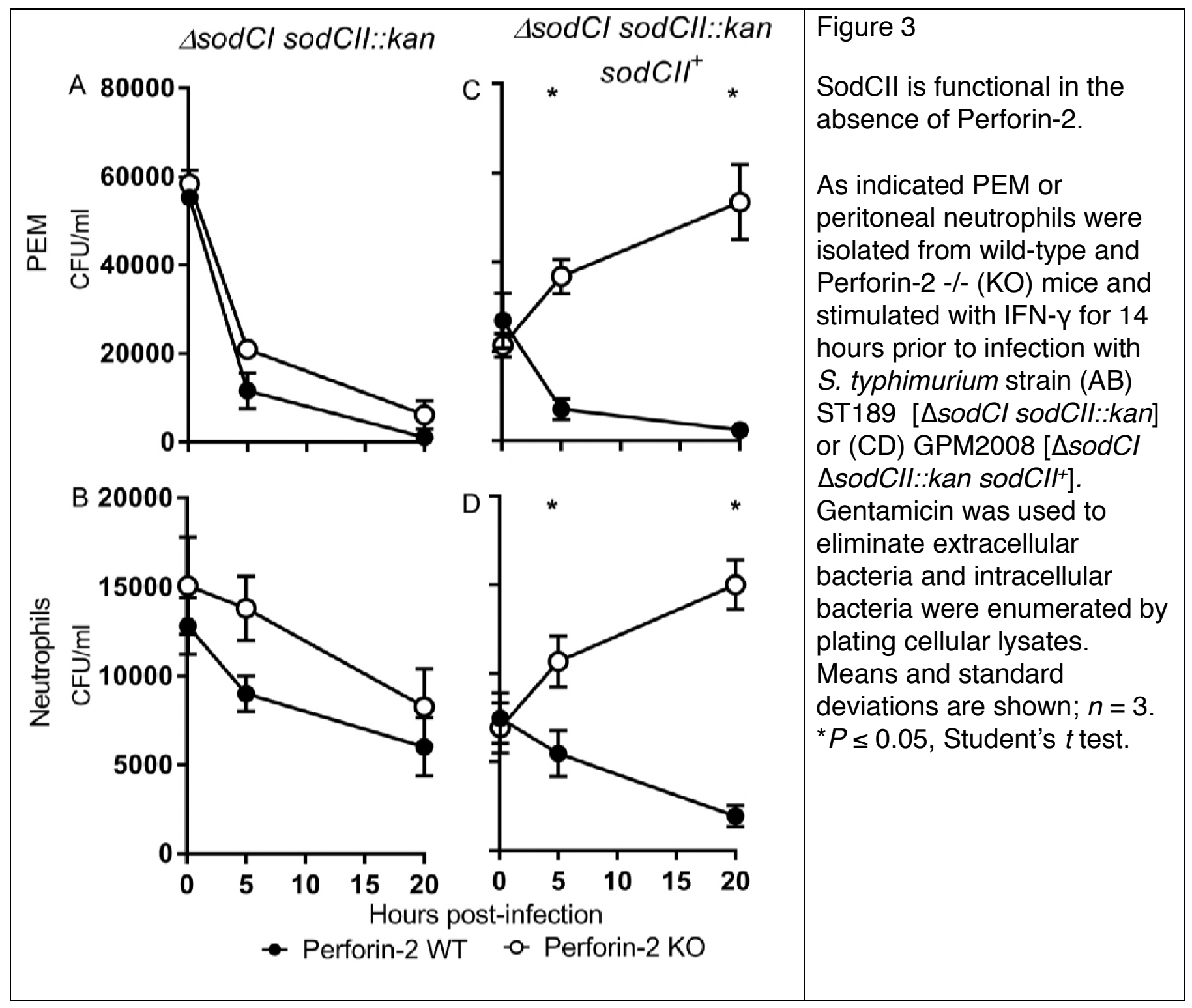




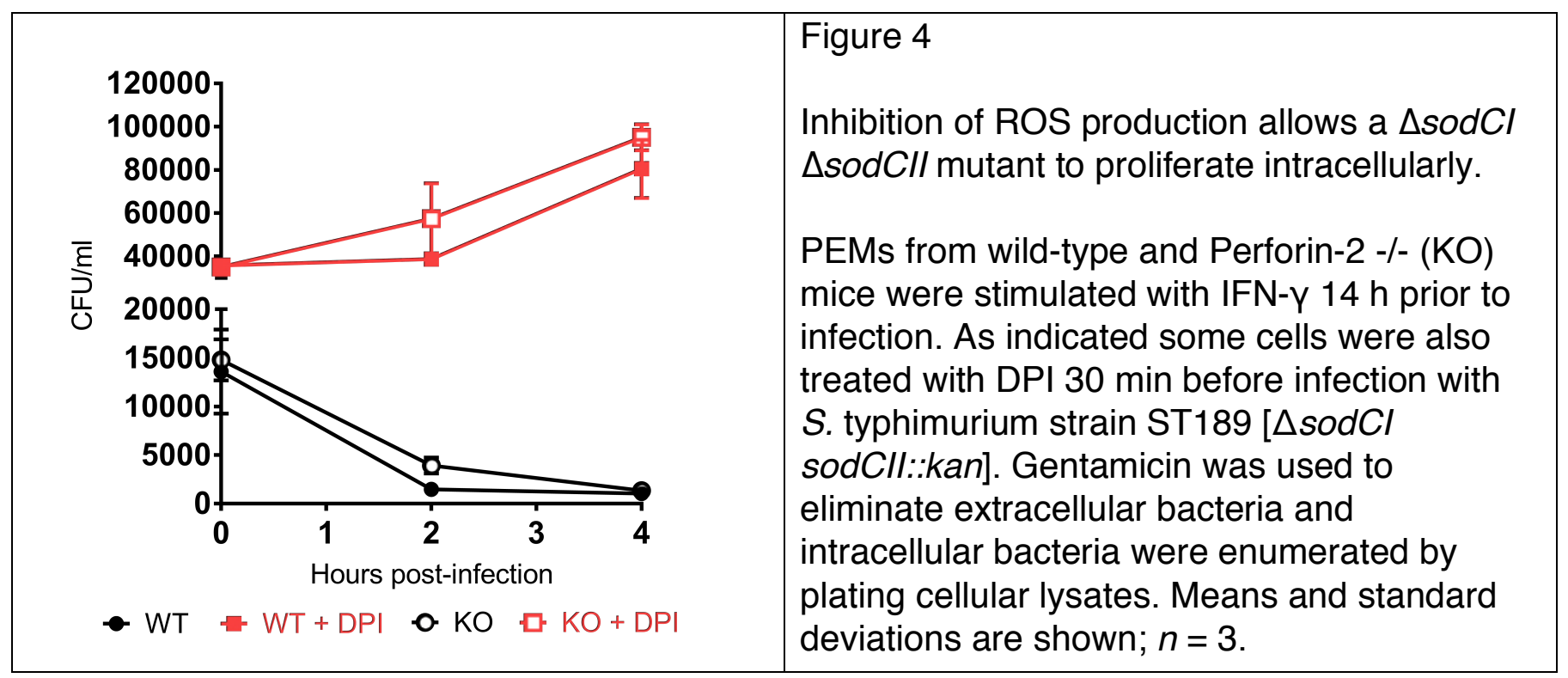

\section{Perforin-2 facilitates the degradation of antigens enclosed within the bacterial envelope.}

Although SodCl and SodCII have similar enzymatic properties, only SodCl provides resistance to endosomal ROS in wild-type phagocytes (Krishnakumar et al., 2004). Studies by the Slauch laboratory have shown that this phenomenon is not the result of differential expression (Krishnakumar et al., 2004). Rather it is due to differential degradation of the two superoxide dismutases; SodCl is protease resistant while SodCll is protease sensitive (Kim et al., 2010; Krishnakumar et al., 2004; Krishnakumar et al., 2007). Thus, SodCll does not protect phagocytosed S. typhimurium because it is proteolytically degraded. However SodCII is functional in Perforin-2 -/- phagocytes (Figure 3). Therefore, we considered it possible that the degradation of SodCII is Perforin-2 dependent. To determine whether or not this is the case we infected wild-type and knockout PEMs with a strain of $S$. typhimurium expressing SodCII-FLAG so that we could track the persistence of SodCII in the periplasm with a monoclonal antibody against the FLAG epitope. We also used antibodies against DnaK and flagellin to monitor the abundance of cytoplasmic and surface antigens respectively. Western blots of intracellular bacteria recovered 18 hours after infection revealed that extracellular flagellin, which was abundant on the surface of the bacteria prior to phagocytosis, was efficiently degraded in both wild-type and knockout PEMs (Figure 5A). In contrast there was a clear difference in the abundance of SodCII in bacteria recovered from Perforin-2 -/- and +/+ PEMs (Figure 5A). This was not due to differences in bacterial load because the difference in SodCll abundance was statistically significant when experimental replicates were quantified and normalized to DnaK of the bacterial cytoplasm (Figure 5B). A further indication that the bacterial loads were similar in these experiments is the fact that the difference in the amount of DnaK normalized to host $\beta$-actin was insignificant while the difference in the amount of SodCII normalized to $\beta$-actin was significant (Figure 5B).

We also examined the degradation of the three bacterial antigens at earlier time points. Because these experiments required significantly more phagocytes we used BMDM which can be obtained at higher yields than PEMs. As with PEMs extracellular flagellin was efficiently degraded in both wild-type and Perforin-2 -/- BMDM (Figure 5C). There was also apparent degradation of both SodCII and DnaK in both types of cells. Nevertheless there was less SodCll in bacteria recovered from wild-type than knockout phagocytes. This difference was statistically significant at 3 and 6 hours when normalized to DnaK even though concurrent degradation of DnaK likely results in an 
188 underestimation of the difference (Figure 5D). The degradation of DnaK also appears to lag that

189 of SodCll; although, it is unclear if this is due to differences in protease accessibility and/or

190 susceptibility. Differences in expression may also contribute to the apparent differences in

191 degradation rates of SodCII compared to DnaK. Relative to $\beta$-actin the differences in SodCII in wild-type compared to Perforin-2 -/- BMDM was significant even at the 1 hour time point. This cannot be due to higher loads of the bacteria in Perforin-2 -/- phagocytes because the amount of DnaK normalized to $\beta$-actin also decreased over time; even in knockout cells. Additionally, extrapolation of our PEM bactericidal assays suggest the differences in bacterial loads is likely to be negligible at early time points; especially, at 1 hour. In aggregate these results demonstrate that Perforin-2 facilitates the degradation of internal -but not extracellular- antigens of phagocytosed bacteria. 


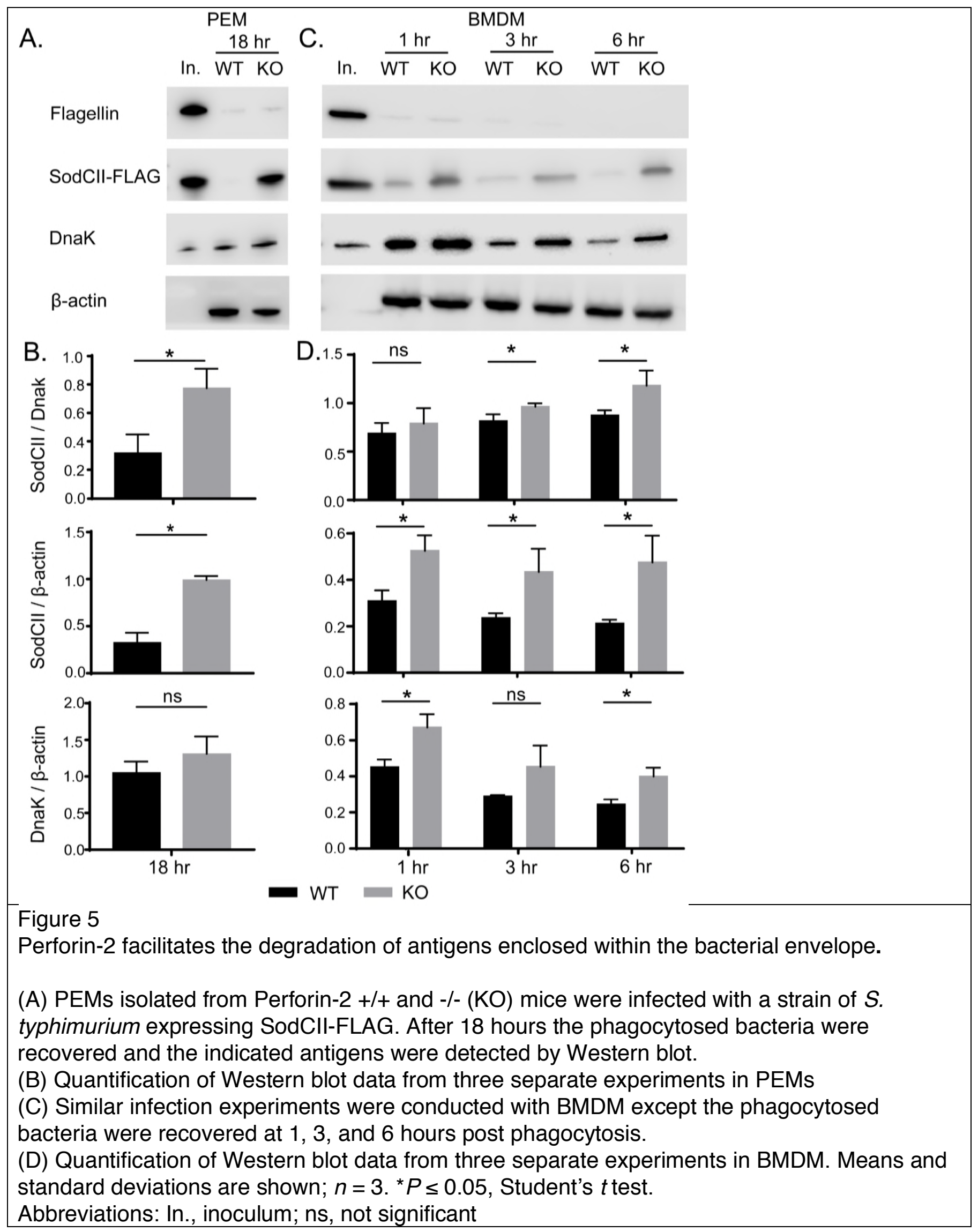


202 Perforin-2 negates SodCII in vivo. Having established that Perforin-2 facilitates the degradation of SodCII in vitro, the relevance of our observations were evaluated in a murine infection model. In brief, wild-type and Perforin-2 -/- mice were inoculated intraperitoneally with a mixture of wildtype $S$. typhimurium and a sodCl mutant at a 1:1 ratio. Four days after infection liver and spleen homogenates were plated on selective media to enumerate the load of each strain. Consistent with previous studies fewer sodCl::kan bacteria were recovered than wild-type bacteria recovered from Perforin- $2+/+$ mice. The derived competitive indices were accordingly low and demonstrate that the sodCl mutant is significantly attenuated in Perforin-2 proficient mice (Figure 6A). In contrast, there was little to no attenuation of the sodCI::kan strain in Perforin-2 -/- mice as indicated by competitive indices near or at 1.0 (Figure 6A). Similar results were obtained with a strain of S. typhimurium that had spontaneously lost the PSLT virulence plasmid (Figure S1) (McClelland et al., 2001). Thus, SodCl is not essential in the absence of Perforin-2.

Based on our in vitro studies the persistence of SodCII was the most likely explanation for the lack of attenuation of the sodClmutant in Perforin-2 knockout mice. Indeed this was found to be the case because a sodCl sodCll double mutant was found to be significantly attenuated relative to wild-type bacteria in Perforin-2 -/- mice (Figure 6B). Furthermore, complementation of the sodCl sodCll double mutant with sodCl/ resulted in a strain that was as virulent as wild-type $S$. typhimurium in Perforin-2 -/- mice (Figure 6C). In fact there appeared to be a slight competitive advantage of the complemented strain over the wild-type strain as indicated by competitive indices $>1$. This could be the result of higher expression levels of sodCll from a heterologous promoter in our construct. In contrast, complementation with sodCl/ failed to rescue the double mutant in wild-type mice (Figure 6C). In aggregate the in vivo studies demonstrate that SodCII confers a protective advantage in Perforin-2 -/- but not wild-type mice. As such they are consistent with our in vitro finding that Perforin-2 facilitates the degradation of SodCII. 


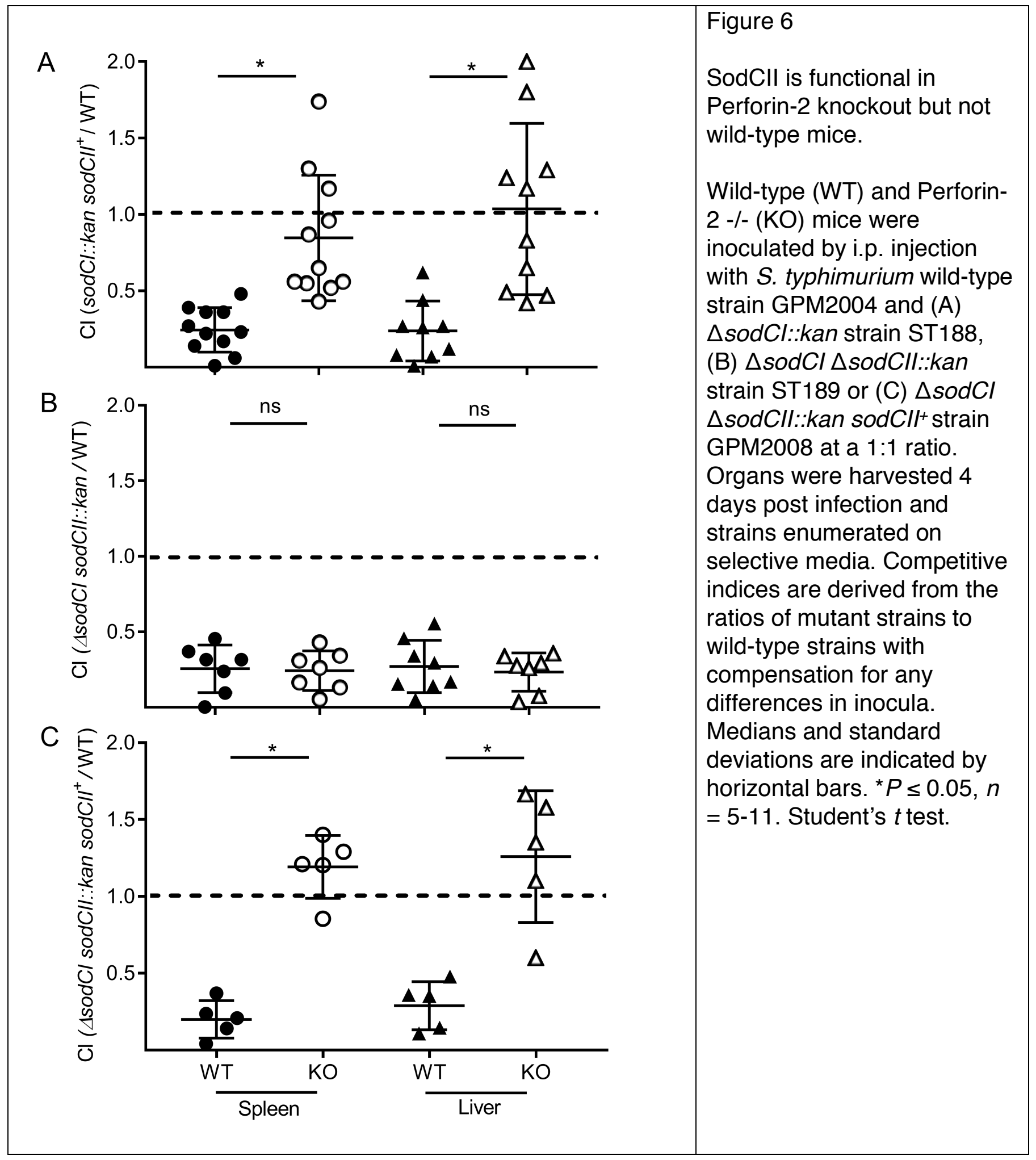

\section{Discussion}

228 Perforin-2 is a type I transmembrane protein that we have previously shown localizes to 229 endosomal vesicles as well as the endoplasmic reticulum, Golgi, and plasma membrane 230 (McCormack et al., 2015a). A separate study that focused on the proteome of endocytic vesicles 231 also found that Perforin-2 is present in endosomes following phagocytosis of latex beads by $\mathrm{J774}$ 
macrophages (Duclos et al., 2011). The same study also found that Perforin-2 was more abundant in late endosomes and lysosomes than early endosomes. Perforin-2 is also coincident with subunits of the phagocytic NAPDH oxidase, proton transporters, and many other antimicrobial effectors of phagosomes and/or the phagolysosomes (Duclos et al., 2011; Nakamura et al., 2014). LPS stimulation of BMDM has also been shown to increase the abundance of Perforin-2 in endolysosomes compared to untreated cells (Nakamura et al., 2014). This is consistent with our own studies in which we reported that LPS results in the accumulation of Perforin-2 in vesicular structures and that Perforin-2 colocalizes with phagocytosed bacteria such as Escherichia coli and S. typhimurium (McCormack et al., 2015a; McCormack et al., 2015b). In aggregate these studies demonstrate that the subcellular distribution of Perforin-2 is consistent with its ability to facilitate the destruction of phagocytosed bacteria.

Although most phagocytosed bacteria are rapidly killed some are able to resist phagocytic antimicrobials and even survive within professional phagocytes. The latter includes $S$.

typhimurium which must survive the respiratory burst and other antimicrobial assaults prior to the formation of Salmonella containing vacuoles; specialized niches within macrophages that afford the pathogen a more favorable environment than phagosomes or phagolysosomes (Anderson and Kendall, 2017). A central player in the survival of the respiratory burst is SodCl; a periplasmic superoxide dismutase that converts superoxide to hydrogen peroxide which is subsequently detoxified by bacterial catalases and peroxidases (Aussel et al., 2011; Hebrard et al., 2009; Slauch, 2011; Storz and Imlay, 1999). The pivotal role of SodCI in protecting Salmonella from ROS has been confirmed by several studies that have shown that sodCI mutants are more susceptible to ROS killing in vitro and less virulent than wild-type Salmonella in vivo (Craig and Slauch, 2009; Fang et al., 1999; Krishnakumar et al., 2004; Krishnakumar et al., 2007). However we have found that a sodCl null mutant is able to proliferate in Perforin-2 deficient phagocytes. Moreover the sodCI null mutant is as virulent as wild-type $S$. typhimurium in Perforin-2 deficient but not proficient- mice. Because we have found that the production of phagocytic ROS is independent of Perforin-2, the survival of the sodCl mutant is not due to differences in ROS production. Rather it is due to the persistence of SodCII, a second periplasmic superoxide disumutase, in Perforin-2 deficient phagocytes. Consistent with our in vitro results we have also found that SodCl and SodCII are functionally redundant in Perforin-2 knockout mice.

The persistence of SodCII was unexpected because previous studies have shown that it is normally degraded by proteases of the phagolysosome (Krishnakumar et al., 2004; Krishnakumar et al., 2007). In contrast SodCl is resistant to proteolytic degradation and thus provides resistance to ROS in the phagolysosome (Krishnakumar et al., 2004). Our results in Perforin- $2+/+$ cells and animals are consistent with these latter studies because sodCII is unable to complement a sodCI sodCII double mutant. However, sodCI/ is able to complement the double mutant in Perforin-2 -/animals and isolated phagocytes. Thus, the presence of Perforin-2 is associated with the inactivation of SodCII.

How does Perforin-2 inactivate SodCII? Consistent with previous studies we have shown that SodCII is proteolytically degraded in the phagosome and/or phagolysosome in Perforin-2 proficient cells (Krishnakumar et al., 2004; Krishnakumar et al., 2007). However, the degradation of SodCII is significantly attenuated in phagocytes lacking Perforin-2. Similar results were observed with cytoplasmic DnaK in BMDM. This was not due to a general defect in protease activity in the phagolysosome because the surface antigen flagellin was degraded whether or not Perforin-2 was present. Thus, Perforin-2 facilitates the degradation of antigens contained within the envelope of phagocytosed bacteria. However, it is unlikely that Perforin-2 is itself a protease because it lacks significant homology to a known protease or protease motif. What Perforin-2 
does have is a MACPF domain (Figure 7) (McCormack and Podack, 2015; Ni and Gilbert, 2017;

Podack and Munson, 2016). This suggest that Perforin-2 is a pore forming protein and putative Perforin-2 pores have been imaged by transmission electron microscropy (McCormack et al., 2015a). However to date it has not been possible to confirm that the imaged structures contain Perforin-2 due to the absence of suitable antibodies. Nor has it been confirmed that the structures are in fact pores. However, other MACPF containing proteins such as complement protein C9 and Perforin have been shown to polymerize and form pores in lipid membranes (Dudkina et al., 2016; Law et al., 2010; Podack et al., 1989; Podack et al., 1982; Podack and Tschopp, 1982). For example, 22 monomers of $\mathrm{C} 9$ polymerize to form a pore in the outer membrane of gram-negative bacteria with an inner diameter of $120 \AA$ (Dudkina et al., 2016; Podack et al., 1982; Tschopp and Podack, 1981). Because Perforin-2 is a type I transmembrane protein with its membrane spanning alpha helix near its carboxy-terminus, the MACPF domain of Perforin-2 would reside in the lumen of endosomes and phagosomes. In this orientation its MACPF domain would reside in the same compartment as phagocytosed bacteria. Thus, we propose that Perforin-2 polymerizes - perhaps after cleavage from its transmembrane domain by a lysosomal protease- and forms pores in the envelope of phagocytosed bacteria (Figure 7). This model is consistent with our experimental observations with $S$. typhimurium since the protease that degrades SodCII would enter the periplasmic space through poly-Perforin-2 pores. Because SodCII is not anchored in the periplasm, it may also diffuse through the pore and be degraded in the lumen of the phagosome (Kim et al., 2010; Krishnakumar et al., 2004; Krishnakumar et al., 2007). In either case SodCII is able to persist in the periplasm and protect the bacterium from the bactericidal effects of ROS when Perforin-2 is absent.

In addition to Perforin-2 there is evidence that the cathelicidins CRAMP and LL-37 also play a role in disrupting the envelope of phagocytosed gram-negative bacteria in murine and human macrophages respectively (Kim et al., 2010; Rosenberger et al., 2004; Sonawane et al., 2011; Stephan et al., 2016). Of particular relevance to this study are previous studies that have shown that CRAMP is active against phagocytosed S. typhimurium (Kim et al., 2010; Rosenberger et al., 2004). In one it was shown that CRAMP inhibits the division of $S$. typhimurium. The result was filamentous bacteria and it was further shown that filamentation was protease dependent (Rosenberger et al., 2004). In another study it was shown that CRAMP is associated with the loss of SodCII from the periplasm of S. typhimurium in vitro (Kim et al., 2010). Moreover SodCII promoted the survival of $S$. typhimurium in CRAMP deficient but not proficient mice. However in the latter study the authors also noted that the loss of CRAMP failed to fully abolish the degradation of SodCII. Our study suggest that this is most likely due to the activity of Perforin-2. Although it is clear that Perforin-2 and cathelicidins can act independently of one another, it remains to be determined if they also act synergistically. In the case of gram-negative bacteria a particularly intriguing model is the possibility that Perforin-2 forms a conduit in the outer membrane through which cathelicidin or other antimicrobial peptides transit to reach the bacterial inner membrane. Alternatively the deployment of independent mechanisms to disrupt the envelope of phagocytosed bacteria may be an insurance strategy against pathogen resistance to any particular mechanism. 


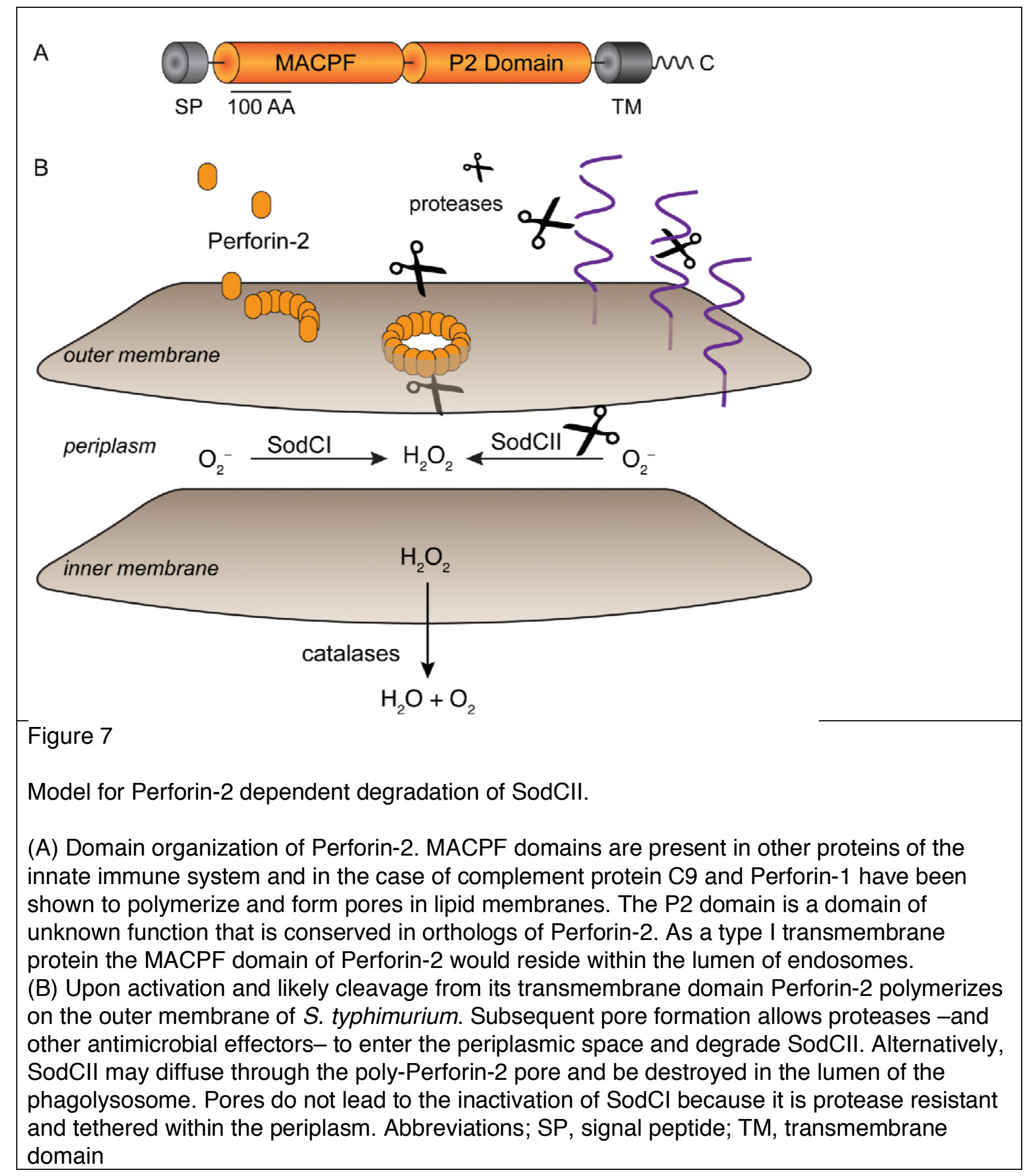

\section{Material And Methods}

323 Mice. Perforin-2 -/- 129X1/SvJ mice were produced at the University of Miami Miller School of 324 Medicine Transgenic Core Facility as previously described (McCormack et al., 2015b). Wild-type $129 \times 1 / S v J$ and Perforin-2 -/- mice of either sex were used at 2 to 6 months of age. Mice received 
food and water ad libitum and were housed at an ambient temperature of $23^{\circ} \mathrm{C}$ on a $12 \mathrm{~h}$ light/dark cycle under specific pathogen-free conditions. Mice were euthanized by $\mathrm{CO}_{2}$ inhalation followed by cervical dislocation. All procedures with animals were reviewed and approved by the University of Miami's Institutional Animal Care and Use Committee.

Strains and Plasmids. Bacterial strains are listed in Table 1. Primer sequences are listed in Table 2. Strains constructed for this study are isogenic derivatives of $S$. typhimurium strain LT2 (Nikaido et al., 1967). Plasmid pKD4 (Datsenko and Wanner, 2000) was used in PCR with primer pairs sodCl-P1/sodC1-P2 or sodCII-P1/sodCll-P2 to generate kanamycin resistance cassettes bracketed by recognition sites for FLP recombinase and flanking sequences targeting sodClor sodCII. Deletions of sodCl or sodCll were generated by $\lambda$ Red-mediated recombination of the cassettes into LT2 as described (Datsenko and Wanner, 2000). Recombinants were selected on LB agar plates with kanamycin. Recombination sites were verified by PCR with flanking primer pairs sodCl-Mfel/sodCl-HindIII for sodCl::kan and sodCII-EcoRI/sodCll-HindIII for sodCIl::kan. For the construction of double deletions FLP recombinase was used to excise the first cassette prior to insertion of the second.

The sodCll gene was cloned from LT2 by PCR with primers sodCII-1238/sodCII-1239. The PCR product was digested with $\mathrm{Xbal}$ and $\mathrm{BamHI}$ then ligated into the same sites of pAH63Tc, a derivative of pAH63 (Haldimann and Wanner, 2001) in which the kanamycin resistance gene was replaced with one conferring resistance to tetracycline. To complement sodCll mutants the resulting plasmid, pAH63Tc-sodCII, was integrated into attB $B_{\lambda}$ of relevant strains by a site specific recombinase as previously described (Haldimann and Wanner, 2001). The chloramphenicol resistant strain GPM2004 was constructed by integration of pCAH63 (Haldimann and Wanner, 2001) into attB $\lambda_{\lambda}$ of LT2. Plasmid pTrc99aSodCIl3flag was constructed by HiFi DNA assembly (New England Biolabs) of three PCR products: one carrying sodCll amplified from pAH63TcsodCII with primers sodCII-1329/sodCII-1330, another carrying a triple FLAG epitope amplified from pSUB11 (Uzzau et al., 2001) with primers 3flag-1331/3flag-1332, and the vector backbone amplfied from pTrc99a (Amann et al., 1988) with primers pTrc99a-1333/pTrc99a-1334. Bacteria were cultured in Luria-Bertani (LB) broth or plates. As appropriate antibiotics were used at the following concentrations: chloramphenicol, $10 \mu \mathrm{g} / \mathrm{ml}$; ampicillin, $100 \mu \mathrm{g} / \mathrm{ml}$; kanamycin, $50 \mu \mathrm{g} / \mathrm{ml}$; tetracycline $7.5 \mu \mathrm{g} / \mathrm{ml}$.

Cell preparation. Peritoneal exudate macrophages (PEMs) were isolated as previously described (Zhang et al., 2008). Briefly, mice were injected intraperitoneally with $1 \mathrm{ml}$ of $4 \%$ Brewer thioglycollate medium and peritoneal exudates were recovered after 4 days. A modified schedule was used to collect PEM for ROS assays (Nathan and Root, 1977). In brief, mice were inoculated on days 1 and 7 , and exudates were collected on day 14. Resting macrophages were collected from the peritoneal cavities of untreated mice. Peritoneal neutrophils were elicited and recovered as previously described (Luo and Dorf, 2001). Briefly mice were injected intraperitoneally with 1 $\mathrm{ml} 9 \%$ casein in PBS (2.7 mM KCl, $4.3 \mathrm{mM} \mathrm{Na}_{2} \mathrm{HPO}_{4}, 1.47 \mathrm{mM} \mathrm{KH}_{2} \mathrm{PO}_{4}, 137 \mathrm{mM} \mathrm{NaCl}, \mathrm{pH} 7.4$ ) containing $0.9 \mathrm{mM} \mathrm{CaCl}_{2}$ and $0.5 \mathrm{mM} \mathrm{MgCl}_{2}$. A second injection was administered $16 \mathrm{~h}$ after the first and exudates collected $3 \mathrm{~h}$ later. Cells were maintained in IMDM (Gibco) supplemented with $10 \%$ fetal bovine serum (FBS) (Gibco) at $37^{\circ} \mathrm{C}$ in $5 \% \mathrm{CO}$. Bone marrow derived macrophage (BMDM) were isolated from the femurs from the Perforin-2 WT and KO mice. The cells were cultured in IMDM medium supplemented with 10\% FBS, 20\% L929 conditioned medium, and 10 $\mathrm{mM} \mathrm{L-glutamine.} \mathrm{BMDM}$ were cultured for 6 days before use, and the culture medium was changed every 2 days.

Intracellular killing assays. Intracellular gentamicin protection assays were performed as previously described (Laroux et al., 2005; Lutwyche et al., 1998; McCormack et al., 2013). Briefly, 
$3 \times 10^{5}$ PEM were seeded in 24 well plates in IMDM, $10 \% \mathrm{FBS}$ and incubated at $37^{\circ} \mathrm{C}$ in $5 \%$

$\mathrm{CO}_{2}$. Murine IFN- $\gamma$ was added 14 hours before infection at a final concentration of $50 \mathrm{ng} / \mathrm{ml}$.

Overnight cultures of bacteria were diluted 33 fold in LB and cultured aerobically at $37^{\circ} \mathrm{C}$ for 3 hpurs to mid-log at which point the optical absorbance of the culture at $600 \mathrm{~nm}$ was ca. 0.6.

Bacteria were added at a multiplicity of infection (MOI) between 20 to 50 and plates incubated for 45 to 60 min to allow for uptake of bacteria. Cells were then washed three times with PBS and fresh culture medium containing $50 \mu \mathrm{g} / \mathrm{ml}$ gentamicin was added to each well to kill extracellular bacteria. After 2 hours the concentration of gentamicin was reduced to $5 \mu \mathrm{g} / \mathrm{ml}$. At selected time points gentamicin was removed by PBS washes and bacteria were recovered by lysis of mammalian cells in strerile water with $0.1 \%$ Triton X-100. Lysates were serially diluted in PBS and the bacteria were enumerated on LB agar plates.

ROS detection. $3 \times 10^{5}$ PEM were seeded in 96-well opaque white plates in $200 \mu$ l of phenol redfree IMDM, 10\% FBS and primed for 14 hours with murine IFN-Y (Biolegend) at a final concentration of $50 \mathrm{ng} / \mathrm{ml}$. Alternatively, $3 \times 10^{5}$ neutrophils were seeded in KRPG buffer (145 $\mathrm{mM} \mathrm{NaCl}, 4.86 \mathrm{mM} \mathrm{KCl}, 5.7 \mathrm{mM}$ sodium phosphate, $0.54 \mathrm{mM} \mathrm{CaCl}_{2}, 1.22 \mathrm{mM} \mathrm{MgSO}$, $5.5 \mathrm{mM}$ Glucose, $\mathrm{pH}$ 7.35). For ROS production in neutrophils, cells were incubated with $1 \mathrm{mM}$ luminol (Sigma) for $3 \mathrm{~min}$. before adding phorbol myristate acetate (PMA)(InvivoGen) or lipopolysaccharides (LPS) (InvivoGen) to a final concentration of $100 \mathrm{ng} / \mathrm{ml}$. Luminescence was read in an EnVision (PerkinElmer) plate reader. Some wells were treated with $10 \mathrm{nM}$ diphenyleneiodonium chloride (DPI) (Sigma) -a NAPDH oxidase inhibitor- for 30 min prior to addition of luminol. The same procedures were used with macrophages except the luminol enhancer Diogenes (National Diagnostics) was also used (Yamazaki et al., 2011).

Recovery of phagocytosed bacteria and immunodetection. S. typhimurium strain GPM2014 / pTrc99aSodCII3flag was cultured aerobically overnight in LB with ampicillin at $37^{\circ} \mathrm{C}$. The bacteria were pelleted, washed with sterile PBS and aliqouts of the inoculum were frozen at $-80{ }^{\circ} \mathrm{C}$ for later analysis. Aliquots of the inoculum were also used to infect wild-type and Perforin-2 -/- PEMs at a multiplicity of infection of about 20-50. After 1 hour incubation, the cells were washed three times with PBS then IMDM with $10 \%$ FBS and $50 \mu \mathrm{g} / \mathrm{ml}$ gentamicin was added to each well. This initial addition of gentamicin marked the 0 hour time point. After 2 hours the concentratio of gentamicin was decreased to $5 \mu \mathrm{g} / \mathrm{ml}$. After 16 hours the cells were washed with PBS three times, then PBS, 0.1\% Triton-X 100 containing a proteinase inhibitor cocktail (Roche, Basel, Switzerland ) was added to each well. After a $5 \mathrm{~min}$. incubation at $37^{\circ} \mathrm{C}$ the cells were manually detached with a cell scraper, the bacterial cells were harvested by centrifuged at $4^{\circ} \mathrm{C}$ at $10,000 \mathrm{~g}$ $\times 10 \mathrm{~min}$, and the supernatant was removed. Recovered phagocytosed bacteria (approximate $10^{6}$ CFU) and bacteria from the original LB culture were boiled in Laemmli loading buffer for $7 \mathrm{~min}$. The same infection procedure was conducted with wild-type and Perforin-2 -/- BMDMs except the phagocytosed bacteria were collected at 1, 3 and 6 hours. The protein samples were separated on $4-20 \%$ gradient SDS-PAGE gels and transferred to nitrocellulose membranes. The membranes were blocked with $5 \%$ non-fat milk in Tris buffered saline containing $0.1 \%$ Tween-20 (TBST) for 2 hours and then incubated at $4^{\circ} \mathrm{C}$ for 16 hours with primary antibodies anti-FliC (1:1000, Invivogen), anti-Flag (1:5000, Sigma) or anti-DnaK (1:5000, Abcam) diluted in TBST with $5 \%$ non-fat milk. After three washes with TBST the membranes were incubated at $37^{\circ} \mathrm{C}$ for 1 hour with anti-mouse horseradish peroxidase-labeled secondary antibody (Jackson ImmunoResearch Laboratories, West Grove, PA, USA) diluted 1:5000 in TBST with 5\% non-fat milk. An Odyssey FC Imaging System (LI-COR, Lincoln, NE, United States) was used to detect and quantify chemilunescence after addition of SuperSignal West Pico Chemiluminescent Substrate (Thermo Fisher Scientific). 
420 Murine infections. Bacteria were cultured overnight in LB medium at $37^{\circ} \mathrm{C}$ and diluted in sterile

421 PBS. For competition assays selected strains of $S$. typhimurium were mixed at a 1:1 ratio.

422 Perforin-2 +/+ and -/- 129X1/SvJ mice were inoculated by intraperitoneal (i.p.) injection. The CFU

423 of each inoculum was quantified by plating and ranged from 500 to 1,000 total CFUs. Spleens

424 and livers were collected four days after inoculation, and then homogenized (Omni International)

425 in $500 \mu \mathrm{l} \mathrm{PBST}$ (PBS, 0.1\% Tween-20). Homogenates were diluted in sterile PBS and plated in

426 triplicate on LB agar with antibiotic selection as appropriate for each strain in the initial inoculum.

427 For each spleen and liver, mean CFUs were used to calculate competitive indices (Cl) according

428 to the following formula: $\mathrm{Cl}=$ (strain A recovered / strain B recovered) / (strain A inoculum / strain

429 B inoculum).

430 Statistical analysis. Statistical analysis was performed with GraphPad Prism 7 software. Data represent the mean \pm standard deviation (SD). Statistical difference was determined by the Student's $t$-test. $P$ values $\leq 0.05$ were considered statistically significant. The number of independent experimental replicates is indicated by $n$.

Table 1 Bacteria strains and plasmids

\begin{tabular}{|c|c|c|}
\hline Strain & Description & Reference \\
\hline LT2 & Wild-type $S$. Typhimurium & $\begin{array}{l}\text { (Nikaido et } \\
\text { al., 1967) }\end{array}$ \\
\hline LT2b & $\begin{array}{l}\text { LT2 derivative that spontaneously lost pSLT } \\
\text { virulence plasmid }\end{array}$ & this study \\
\hline GPM2004 & LT2 attB ::pCAH63, chloramphenicol resistant & this study \\
\hline GPM2004b & LT2b attB ::pCAH63, chloramphenicol resistant & this study \\
\hline ST188 & LT2 $\Delta$ sodCl::kan & this study \\
\hline ST188b & LT2b $\Delta$ sodCl::kan & this study \\
\hline ST189 & LT2 $\Delta$ sodCl $\Delta$ sodCll::kan & this study \\
\hline GPM2008 & LT2 $\Delta$ sodCl $\Delta$ sodCII::kan attB入::pAH63Tc-sodCll & this study \\
\hline GPM2014 & LT2 pTrc99aSodCll3flag & this study \\
\hline
\end{tabular}


439 Table 2 Oligonucleotide Primers

\begin{tabular}{|c|c|}
\hline Primer & Sequence $^{a}\left(5^{\prime}-3^{\prime}\right)$ \\
\hline sodCl-P1 & $\begin{array}{l}\text { TACACAATATTGTCGCTGGTAGCTGGTGCGCTCATCAGTTGT } \\
\text { GTAGGCTGGAGCTGCTTC }\end{array}$ \\
\hline sodCl-P2 & $\begin{array}{l}\text { ATTGTCACCGCCTTTATGGATCATCAATGAGTGACCTTTCAT } \\
\text { ATGAATATCCTCCTTAGT }\end{array}$ \\
\hline sodCl-Mfel & TTTCAATTGATTAATGGTATTTACGATACAACC \\
\hline sodCl-HindIII & TTTAAGCTTATGGCTATGTTGCTGTTATTTCTC \\
\hline sodCII-P1 & $\begin{array}{l}\text { GCAGGCCGCCAGCGAGAAAGTAGAGATGAATCTGGTGACT } \\
\text { GTGTAGGCTGGAGCTGCTTC }\end{array}$ \\
\hline sodCII-P2 & $\begin{array}{l}\text { CGCCGCCGCCGAGCGGTTTCGGCTGATCGGACATGTTATCA } \\
\text { TATGAATATCCTCCTTAGT }\end{array}$ \\
\hline sodCII-EcoRI & TTTGAATTCAACAGGCGACCACATGTAACGGAG \\
\hline sodCII-HindIII & TTTAAGCTTCACTGGCTCCGGGTTATTTAATGA \\
\hline sodCII-1238 & GCGTCTAGAGGGTTATGACGTGCCGTAATC \\
\hline sodCII-1239 & $\begin{array}{l}\text { GCGGGATCCTCTTCACTTGTCGTCATCGTCCTTGTAGTCTTT } \\
\text { AATGACGCCGCAGGCGTAAC }\end{array}$ \\
\hline sodCII-1329 & ACCCGGGGATCCTTTATGACGTGCCGTAATCGC \\
\hline sodCII-1330 & TGTAGTCGAATTCTTTAATGACGCCGCAGGCGTAA \\
\hline $3 f l a g-1331$ & CGGCGTCATTAAAGAATTCGACTACAAAGACCATGACG \\
\hline 3flag-1332 & CAAAACAGCCAAGGGAACTTCGAAGCAGCTCCAG \\
\hline pTrc99a-1333 & GCTTCGAAGTTCCCTTGGCTGTTTTGGCGGATGA \\
\hline pTrc99a-1334 & CGGCACGTCATAAAGGATCCCCGGGTACCGAG \\
\hline
\end{tabular}

aUnderlined nucleotides indicate primer/template mismatches. 


\section{Acknowledgments}

Research reported in this publication was supported by Grant Number Al110810 from the National Institute of Allergy and Infectious Diseases of the National Institutes of Health (NIAID

$\mathrm{NIH}$ ). Its contents are solely the responsibility of the authors and do not necessarily represent the official views of the $\mathrm{NIH}$.

\section{Author Contributions}

452 Conceptualization, F.B., R.M.M., M.G.L., and G.P.M.; Methodology, F.B., R.M.M., and G.P.M.; Investigation, F.B.; Validation, F.B and G.P.M.; Formal Analysis, F.B.; Resources, S.H., G.V.P., and R.M.M.; Writing - Original Draft, F.B. and G.P.M.; Writing - Review \& Editing, F.B., R.M.M., S.H., G.V.P., M.G.L., and G.P.M.; Visualization, F.B. and G.P.M.; Supervision, M.G.L. and G.P.M.; Funding Acquistion, G.P.M.

\section{Declaration of Interests}

458 The authors declare no competing interests.

\section{References}

Amann, E., Ochs, B., and Abel, K.J. (1988). Tightly regulated tac promoter vectors useful for the expression of unfused and fused proteins in Escherichia coli. Gene 69, 301-315.

Anderson, C.J., and Kendall, M.M. (2017). Salmonella enterica Serovar Typhimurium Strategies for Host Adaptation. Frontiers in microbiology 8, 1983.

Aussel, L., Zhao, W., Hebrard, M., Guilhon, A.A., Viala, J.P., Henri, S., Chasson, L., Gorvel, J.P., the host oxidative burst. Molecular microbiology 80, 628-640.

Benard, E.L., Racz, P.I., Rougeot, J., Nezhinsky, A.E., Verbeek, F.J., Spaink, H.P., and Meijer, A.H. (2015). Macrophage-expressed perforins mpeg1 and mpeg1.2 have an anti-bacterial function in zebrafish. Journal of innate immunity 7, 136-152.

Cederlund, A., Gudmundsson, G.H., and Agerberth, B. (2011). Antimicrobial peptides important in innate immunity. The FEBS journal 278, 3942-3951.

Datsenko, K.A., and Wanner, B.L. (2000). One-step inactivation of chromosomal genes in the United States of America 97, 6640-6645. 
481 Dudkina, N.V., Spicer, B.A., Reboul, C.F., Conroy, P.J., Lukoyanova, N., Elmlund, H., Law, R.H., 482 Ekkel, S.M., Kondos, S.C., Goode, R.J., et al. (2016). Structure of the poly-C9 component of the complement membrane attack complex. Nature communications 7, 10588.

484 Ellison, R.T., 3rd, and Giehl, T.J. (1991). Killing of gram-negative bacteria by lactoferrin and 485 lysozyme. The Journal of clinical investigation 88, 1080-1091.

486 Fang, F.C., DeGroote, M.A., Foster, J.W., Baumler, A.J., Ochsner, U., Testerman, T., Bearson, 487 S., Giard, J.C., Xu, Y., Campbell, G., and Laessig, T. (1999). Virulent Salmonella typhimurium 488 has two periplasmic $\mathrm{Cu}, \mathrm{Zn}$-superoxide dismutases. Proceedings of the National Academy of 489 Sciences of the United States of America 96, 7502-7507.

490 Fields, K.A., McCormack, R., de Armas, L.R., and Podack, E.R. (2013). Perforin-2 restricts 491 growth of Chlamydia trachomatis in macrophages. Infection and immunity 81, 3045-3054.

492 Gallo, R.L., Kim, K.J., Bernfield, M., Kozak, C.A., Zanetti, M., Merluzzi, L., and Gennaro, R. 493 (1997). Identification of CRAMP, a cathelin-related antimicrobial peptide expressed in the 494 embryonic and adult mouse. The Journal of biological chemistry 272, 13088-13093.

495 Gudmundsson, G.H., Agerberth, B., Odeberg, J., Bergman, T., Olsson, B., and Salcedo, R. 496 (1996). The human gene FALL39 and processing of the cathelin precursor to the antibacterial 497

Haldimann, A., and Wanner, B.L. (2001). Conditional-replication, integration, excision, and retrieval plasmid-host systems for gene structure-function studies of bacteria. Journal of bacteriology 183, 6384-6393.

Hebrard, M., Viala, J.P., Meresse, S., Barras, F., and Aussel, L. (2009). Redundant hydrogen peroxide scavengers contribute to Salmonella virulence and oxidative stress resistance. Journal of bacteriology 191, 4605-4614.

Henzler Wildman, K.A., Lee, D.K., and Ramamoorthy, A. (2003). Mechanism of lipid bilayer disruption by the human antimicrobial peptide, LL-37. Biochemistry 42, 6545-6558.

Karimi, G., Houee Levin, C., Dagher, M.C., Baciou, L., and Bizouarn, T. (2014). Assembly of phagocyte NADPH oxidase: A concerted binding process? Biochimica et biophysica acta 1840, 3277-3283. effectors in the phagosome allows SodCIl to contribute to virulence in Salmonella enterica serovar Typhimurium. Journal of bacteriology 192, 2140-2149.

512 Krishnakumar, R., Craig, M., Imlay, J.A., and Slauch, J.M. (2004). Differences in enzymatic 513 properties allow SodCl but not SodCIl to contribute to virulence in Salmonella enterica serovar 514 Typhimurium strain 14028. Journal of bacteriology 186, 5230-5238. 
Laroux, F.S., Romero, X., Wetzler, L., Engel, P., and Terhorst, C. (2005). Cutting edge: MyD88 controls phagocyte NADPH oxidase function and killing of gram-negative bacteria. Journal of immunology 175, 5596-5600.

Law, R.H., Lukoyanova, N., Voskoboinik, I., Caradoc-Davies, T.T., Baran, K., Dunstone, M.A., D'Angelo, M.E., Orlova, E.V., Coulibaly, F., Verschoor, S., et al. (2010). The structural basis for membrane binding and pore formation by lymphocyte perforin. Nature 468, 447-451.

Lichtenheld, M.G., Olsen, K.J., Lu, P., Lowrey, D.M., Hameed, A., Hengartner, H., and Podack, E.R. (1988). Structure and function of human perforin. Nature 335, 448-451.

Luo, Y., and Dorf, M.E. (2001). Isolation of mouse neutrophils. Current protocols in immunology Chapter 3, Unit 320.

Lutwyche, P., Cordeiro, C., Wiseman, D.J., St-Louis, M., Uh, M., Hope, M.J., Webb, M.S., and Finlay, B.B. (1998). Intracellular delivery and antibacterial activity of gentamicin encapsulated in $\mathrm{pH}$-sensitive liposomes. Antimicrobial agents and chemotherapy 42, 2511-2520.

Martinez, R.J., and Carroll, S.F. (1980). Sequential metabolic expressions of the lethal process in human serum-treated Escherichia coli: role of lysozyme. Infection and immunity 28, 735-745.

McClelland, M., Sanderson, K.E., Spieth, J., Clifton, S.W., Latreille, P., Courtney, L., Porwollik, S., Ali, J., Dante, M., Du, F., et al. (2001). Complete genome sequence of Salmonella enterica serovar Typhimurium LT2. Nature 413, 852-856.

McCormack, R., Bahnan, W., Shrestha, N., Boucher, J., Barreto, M., Barrera, C.M., Dauer, E.A., Freitag, N.E., Khan, W.N., Podack, E.R., and Schesser, K. (2016). Perforin-2 Protects Host Cells and Mice by Restricting the Vacuole to Cytosol Transitioning of a Bacterial Pathogen. Infection and immunity $84,1083-1091$.

McCormack, R., de Armas, L.R., Shiratsuchi, M., Ramos, J.E., and Podack, E.R. (2013). Inhibition of intracellular bacterial replication in fibroblasts is dependent on the perforin-like protein (perforin-2) encoded by macrophage-expressed gene 1. Journal of innate immunity 5, 185-194.

McCormack, R., and Podack, E.R. (2015). Perforin-2/Mpeg1 and other pore-forming proteins throughout evolution. Journal of leukocyte biology 98, 761-768.

McCormack, R.M., de Armas, L.R., Shiratsuchi, M., Fiorentino, D.G., Olsson, M.L., Lichtenheld, M.G., Morales, A., Lyapichev, K., Gonzalez, L.E., Strbo, N., et al. (2015a). Perforin-2 is essential for intracellular defense of parenchymal cells and phagocytes against pathogenic bacteria. eLife 4.

McCormack, R.M., Lyapichev, K., Olsson, M.L., Podack, E.R., and Munson, G.P. (2015b). Enteric pathogens deploy cell cycle inhibiting factors to block the bactericidal activity of Perforin-2. eLife 4.

Nakamura, N., Lill, J.R., Phung, Q., Jiang, Z., Bakalarski, C., de Maziere, A., Klumperman, J., Schlatter, M., Delamarre, L., and Mellman, I. (2014). Endosomes are specialized platforms for bacterial sensing and NOD2 signalling. Nature 509, 240-244. 
bioRxiv preprint doi: https://doi.org/10.1101/274878; this version posted March 2, 2018. The copyright holder for this preprint (which was not certified by peer review) is the author/funder, who has granted bioRxiv a license to display the preprint in perpetuity. It is made available under aCC-BY-NC-ND 4.0 International license.

555 Nathan, C.F., and Root, R.K. (1977). Hydrogen peroxide release from mouse peritoneal macrophages: dependence on sequential activation and triggering. The Journal of experimental medicine 146, 1648-1662.

Nauseef, W.M. (2004). Assembly of the phagocyte NADPH oxidase. Histochemistry and cell biology 122, 277-291.

Ni, T., and Gilbert, R.J.C. (2017). Repurposing a pore: highly conserved perforin-like proteins with alternative mechanisms. Philos Trans R Soc Lond B Biol Sci 372.

Nikaido, H., Levinthal, M., Nikaido, K., and Nakane, K. (1967). Extended deletions in the histidinerough-B region of the Salmonella chromosome. Proceedings of the National Academy of Sciences of the United States of America 57, 1825-1832.

Panday, A., Sahoo, M.K., Osorio, D., and Batra, S. (2015). NADPH oxidases: an overview from structure to innate immunity-associated pathologies. Cellular \& molecular immunology 12, 5-23.

Podack, E.R., and Munson, G.P. (2016). Killing of Microbes and Cancer by the Immune System with Three Mammalian Pore-Forming Killer Proteins. Frontiers in immunology 7, 464. perforin. Curr Top Microbiol Immunol 140, 11-17.

Podack, E.R., Tschoop, J., and Muller-Eberhard, H.J. (1982). Molecular organization of C9 within the membrane attack complex of complement. Induction of circular C9 polymerization by the C5b8 assembly. The Journal of experimental medicine 156, 268-282.

Podack, E.R., and Tschopp, J. (1982). Polymerization of the ninth component of complement (C9): formation of poly(C9) with a tubular ultrastructure resembling the membrane attack complex of complement. Proceedings of the National Academy of Sciences of the United States of America 79, 574-578.

Rosenberger, C.M., Gallo, R.L., and Finlay, B.B. (2004). Interplay between antibacterial effectors: a macrophage antimicrobial peptide impairs intracellular Salmonella replication. Proceedings of the National Academy of Sciences of the United States of America 101, 2422-2427. question. Molecular microbiology $80,580-583$. Appelberg, R., and Griffiths, G. (2011). Cathelicidin is involved in the intracellular killing of mycobacteria in macrophages. Cellular microbiology 13, 1601-1617. Isolation of a novel macrophage-specific gene by differential cDNA analysis. Blood 85, 16201629. 
591 Stephan, A., Batinica, M., Steiger, J., Hartmann, P., Zaucke, F., Bloch, W., and Fabri, M. (2016).

592 LL37:DNA complexes provide antimicrobial activity against intracellular bacteria in human

593 macrophages. Immunology 148, 420-432.

594 Storz, G., and Imlay, J.A. (1999). Oxidative stress. Current opinion in microbiology 2, 188-194.

595 Thiery, J., Keefe, D., Boulant, S., Boucrot, E., Walch, M., Martinvalet, D., Goping, I.S., Bleackley, 596 R.C., Kirchhausen, T., and Lieberman, J. (2011). Perforin pores in the endosomal membrane 597 trigger the release of endocytosed granzyme B into the cytosol of target cells. Nat Immunol 12, $598 \quad 770-777$.

599 Tschopp, J., and Podack, E.R. (1981). Membranolysis by the ninth component of human 600 complement. Biochemical and biophysical research communications 100, 1409-1414.

601 Turner, J., Cho, Y., Dinh, N.N., Waring, A.J., and Lehrer, R.I. (1998). Activities of LL-37, a 602 cathelin-associated antimicrobial peptide of human neutrophils. Antimicrobial agents and 603 chemotherapy 42, 2206-2214.

604 Uzzau, S., Figueroa-Bossi, N., Rubino, S., and Bossi, L. (2001). Epitope tagging of chromosomal 605 genes in Salmonella. Proceedings of the National Academy of Sciences of the United States of 606 America 98, 15264-15269.

607 Voskoboinik, I., Whisstock, J.C., and Trapani, J.A. (2015). Perforin and granzymes: function, 608 dysfunction and human pathology. Nat Rev Immunol 15, 388-400.

609 Wiesner, J., and Vilcinskas, A. (2010). Antimicrobial peptides: the ancient arm of the human 610 immune system. Virulence 1, 440-464.

611 Yamazaki, T., Kawai, C., Yamauchi, A., and Kuribayashi, F. (2011). A highly sensitive 612 chemiluminescence assay for superoxide detection and chronic granulomatous disease 613 diagnosis. Tropical medicine and health 39, 41-45.

614 Zanetti, M. (2004). Cathelicidins, multifunctional peptides of the innate immunity. Journal of 615 leukocyte biology 75, 39-48.

616 Zhang, X., Goncalves, R., and Mosser, D.M. (2008). The isolation and characterization of murine 617 macrophages. Current protocols in immunology Chapter 14, Unit 1411. 